\title{
Neurofibromatosis type 1 (NF1): a protein truncation assay yielding identification of mutations in $73 \%$ of patients
}

\author{
Vicki Murtif Park, Enikö Kármán Pivnick
}

\begin{abstract}
Neurofibromatosis type 1 (NF1) is caused by mutations in a tumour suppressor gene located on chromosome 17 (17q11.2). Disease causing mutations are dispersed throughout the gene, which spans 350 kilobases and includes 59 exons. A common consequence of NF1 mutations is introduction of a premature stop codon, and the majority of mutant genes encode truncated forms of neurofibromin. We used a protein truncation assay to screen for mutations in 15 NF1 patients and obtained positive results in 11 of them (73\%). Sequencing of cDNA and genomic DNA yielded identification of 10 different mutations, including four splicing errors, three small deletions, two nonsense mutations, and one small insertion. Nine mutations were predicted to cause premature termination of translation, while one mutation caused in frame deletion as a result of exon skipping. In one other case involving abnormal splicing, five different aberrantly spliced transcripts were detected. One germline nonsense mutation (R1306X, 3916C $>$ T) corresponded to the same base change that occurs by mRNA editing in normal subjects. The second nonsense mutation (R2496X) was the sole germline mutation that has been previously described. The subjects studied represented typically affected NF1 patients and no correlations between genotype and phenotype were apparent. A high incidence of ocular hypertelorism was observed. (F Med Genet 1998;35:813-820)
\end{abstract}

Department of

Obstetrics and Gynecology, University of Tennessee, Memphis, 711 Jefferson Avenue, Room 429, Memphis, TN 38163, USA

V M Park

Department of Pediatrics, University of Tennessee, Memphis, TN 38163 , USA

V M Park

E K Pivnick

Correspondence to: Dr Park. tended to focus on one portion of the gene at a time rather than on the entire coding region. Since disease causing mutations are dispersed throughout the gene, these studies have detected mutations in a relatively small proportion of subjects. For example, one study used chemical mismatch cleavage to screen $70 \%$ of the coding region in $25 \mathrm{NF} 1$ patients and identified potentially disease causing mutations in $28 \%$ of subjects. ${ }^{3}$ Other studies focused on smaller regions of the gene and detected mutations in a correspondingly smaller fraction of subjects. ${ }^{4-9}$ Other than protein truncation testing, the only reported method developed to screen the entire coding region used long RT-PCR to amplify the entire $8.5 \mathrm{~kb}$ open reading frame and full length RT-PCR products were digested with restriction enzymes. ${ }^{10}$ By this method, mutations associated with deletion or insertion within the mRNA altered the size of the RT-PCR product and the restriction digest improved the resolution with which size changes could be detected. Still, the authors predicted the method to yield positive results in only $30 \%$ of previously reported NF1 mutations.

Compared to other methods, the protein truncation test (PTT) provides improved efficiency in detecting NF1 mutations. ${ }^{11}$ First developed for use in Duchenne muscular dystrophy (DMD) $)^{12}$ and familial adenomatous polyposis (APC), ${ }^{13}$ PTT has been applied to mutation screening in numerous genes ${ }^{14-18}$ including NF1..$^{11}{ }^{19} 20$ primary advantage of the method is its ability to screen an entire coding region for any type of sequence alteration that affects the size of the encoded protein. This is accomplished by using one or more amplified segments of the gene as substrate for coupled in vitro transcription and translation. Mutations causing premature termination of translation within a given segment yield protein products of less than the expected size. Such truncating mutations are common in NF1, where approximately $80 \%$ of fully characterised mutations detected by methods other than PTT are predicted to lead to severe truncation of neurofibromin. ${ }^{2}$ In the current study, mutations were identified in 11 of the 15 patients screened $(73 \%)$, which is the highest rate of mutation detection reported in a study of typical NF1 patients.

\section{Subjects, material, and methods} SUBJECTS

All study participants were recruited from the clinic population of the University of Tennessee, Memphis NF Clinic according to an IRB exhibits a high mutation rate, and approximately $50 \%$ of index cases represent new mutations. $^{2}$

Because of the large size of the NF1 gene, traditional methods of mutation screening have 
Table 1 Summary of PTT results and clinical descriptions

\begin{tabular}{|c|c|c|c|c|c|c|c|c|c|c|c|c|}
\hline $\begin{array}{l}\text { PTT } \\
\text { Segment }\end{array}$ & $c D N A$ mutation & $\begin{array}{l}\text { Encoded } \\
\text { Protein (aa) }\end{array}$ & DNA mutation & Case ID & $\begin{array}{l}\text { Age } \\
(y)\end{array}$ & Sex & Ethnicity & $\begin{array}{l}\text { Sporadic }(S) \\
\text { familial }(F)\end{array}$ & $\begin{array}{l}\text { CAL } \\
\text { spots }\end{array}$ & Freckling & $\begin{array}{l}\text { Plex } \\
\text { neurofi }\end{array}$ & $i b \frac{C}{\mathbb{D}}$ \\
\hline 1 & 480-586del +others & $1-163$ & $?$ & $95-15$ & 6 & $\mathbf{F}$ & White & Adopted & + & + & - & \\
\hline 1 & $587-654 \mathrm{del}$ & $1-206$ & $587-3 \mathrm{C}>\mathrm{A}$ & $96-62$ & 24 & $\mathbf{F}$ & White & $\mathrm{F}$ & + & + & + & $\frac{0}{2}$ \\
\hline 2 & $1393-1527 \mathrm{del}$ & $\begin{array}{l}1-464 / / \\
510-2818\end{array}$ & $\mathrm{~K} 505 \mathrm{E}(1513 \mathrm{~A}>\mathrm{G})$ & $96-21$ & 7 & $\mathbf{F}$ & White & $S$ & + & + & -- & ? \\
\hline 2 & $1756-1759 \mathrm{del}$ & $1-602$ & $1756-1759 \mathrm{del}$ & $96-77$ & 9 & $\mathbf{F}$ & Af Am & $\mathrm{F}$ & + & + & - & $\stackrel{\bar{\omega}}{+}$ \\
\hline 3 & $2320-2321$ ins $A$ & $1-774$ & $2320-2321$ ins $A$ & $96-53$ & 5 & $\mathbf{F}$ & White & $\mathrm{S}$ & + & + & -- & $\overline{0}$ \\
\hline 4 & 3151-3152delGG & $1-1057$ & 3151-3152delGG & $96-45$ & 24 & $\mathbf{F}$ & White & $\mathrm{F}$ & + & + & + & \\
\hline 4 & 3151-3152delGG & $1-1057$ & 3151-3152delGG & $96-65$ & 22 & $\mathbf{F}$ & White & $\mathrm{F}$ & + & + & -- & \\
\hline 5 & R1306X & $1-1305$ & $\mathrm{R} 1306 \mathrm{X}(3916 \mathrm{C}>\mathrm{T})$ & $96-43$ & 8 & $\mathbf{F}$ & Af Am & $S$ & + & + & - & $=$ \\
\hline 7 & 5453delT & $1-1840$ & 5453delT & $96-70$ & 7 & $\mathbf{F}$ & White & $\mathrm{F}$ & + & - & - & $\overrightarrow{\mathbb{D}}$ \\
\hline 8 & $6580-6641 \mathrm{del}$ & $1-2198$ & $6641+1 \mathrm{G}>\mathrm{T}$ & $96-42$ & 4 & $M$ & White & $\mathrm{S}$ & + & -- & - & \\
\hline 9 & R2496X & $1-2495$ & $\mathrm{R} 2496 \mathrm{X}(7486 \mathrm{C}>\mathrm{T})$ & $96-41$ & 3 & $\mathbf{M}$ & Af Am & $S$ & + & + & + & 心 \\
\hline Neg & - & - & - & $96-73$ & 7 & F & White & $\mathrm{S}$ & + & + & + & $\overrightarrow{0}$ \\
\hline $\mathrm{Neg}$ & - & - & - & $96-51$ & 6 & $\mathbf{M}$ & White & $\mathrm{S}$ & + & + & -- & P \\
\hline Neg & - & - & - & $96-55$ & 8 & $M$ & Af Am & $\mathbf{F}$ & + & + & - & w \\
\hline $\mathrm{Neg}$ & - & - & 一 & $96-84$ & 7 & $M$ & White & $\mathbf{F}$ & + & + & - & $\stackrel{\text { O) }}{3}$ \\
\hline
\end{tabular}

aa = amino acids, MRI UBS = hyperintense T2 signal on MRI, ND = not determined, LD = learning disabilities, ADHD = attention deficit/hyperactivity disord Key to "Other": (A) Malignant peripheral nerve sheath tumour. (B) Low grade cerebral astrocytoma. (C) Partial heterochromia of iris. (D) Pulmonary stenosis. (E) Mental retardation with autistic features. (F) Cerebral palsy. (G) Severe behavioural problem. (H) Eyelid ptosis. (I) Strabismus.

approved research protocol. The clinical diagnosis of NF1 was based on the NIH Consensus Conference criteria. ${ }^{21}$ Clinical descriptions are given in table 1 . None of the participants had the Noonan-NF phenotype. In some cases, blood specimens were obtained from other affected family members or from unaffected parents in addition to the index case. Informed consent was obtained from all study participants. Mutation screening was performed on 15 affected subjects who were presumed to be unrelated based on family history (including names of all first and second degree relatives).

RT-PCR

Peripheral blood from subjects was used to prepare total cellular RNA and genomic DNA. For RNA, leucocytes were isolated by ficoll gradient centrifugation followed by acid guanidinium thiocyanate-phenol-chloroform extraction. ${ }^{22}$ RNA was recovered following alcohol precipitation. Genomic DNA was prepared using a high salt precipitation method (Gentra Systems Inc, Minneapolis, MN).

Total cellular RNA was treated with DNase I and then used to prepare cDNA. Reverse transcriptase reactions included 5-10 $\mu \mathrm{g}$ RNA, random hexamers, and Superscript II reverse transcriptase (Gibco BRL, Gaithersburg, MD) in a final volume of $60 \mu \mathrm{l}$. PCR reactions contained $2 \mu \mathrm{l} \mathrm{cDNA}, 10 \mathrm{mmol} / 1$ Tris- $\mathrm{HCl}, \mathrm{pH}$ 8.3, $50 \mathrm{mmol} / 1 \mathrm{KCl}, 2 \mathrm{mmol} / 1 \mathrm{MgCl}_{2}, 0.2$ $\mathrm{mmol} / \mathrm{l}$ each dATP, dTTP, dCTP, and dGTP, $0.4 \mu \mathrm{mol} / 1$ each forward and reverse primer (table 2), 2.5 units AmpliTaq Gold polymerase (Perkin Elmer, Foster City, CA), and 0.02 units Vent polymerase (New England Biolabs, Beverly, MA). All forward primers included a leader sequence consisting of a T7 transcription promoter plus eukaryotic translation initiation signals (table 2). PCR parameters were 40 cycles of $94^{\circ} \mathrm{C}$ for 30 seconds, $58^{\circ} \mathrm{C}$ for 30 seconds, and $72^{\circ} \mathrm{C}$ for 90 seconds. The initial cycle was preceded by nine minutes at $94^{\circ} \mathrm{C}$ to activate AmpliTaq Gold polymerase in addition to denaturing the template, and the last cycle was followed by five minutes at $72^{\circ}$ An aliquot of each PCR reaction was analys by agarose gel electrophoresis to monitor yield and integrity of the product. Typical yield w\& 0.5-1.0 $\mu \mathrm{g}$ per $50 \mu \mathrm{l}$ PCR reaction.

IN VITRO TRANSCRIPTION AND TRANSLATION Approximately $75 \mathrm{ng}$ of each RT-PCR produ@ was used in $12.5 \mu$ l coupled transcription and translation reactions according to recommendations of the supplier of the reticulocy lysate system (Promega Corp, Madison, WIS. Reactions included ${ }^{35} \mathrm{~S}$-methionine (Ame? sham, Arlington Heights, IL). Proteins weft analysed by Laemmli SDS polyacrylamide gê] electrophoresis using $15 \%$ acrylamide (BiơRad, Hercules, CA) and $20 \mathrm{~cm}$ gels. Speci mens were batched by segment to facilitate comparison of segment specific band pattern. Gels were treated with Entensify (Dupoget NEN, Boston, MA), dried, and exposed to ray film. The sizes of protein bands observed by fluorography were estimated by compari son to prestained protein molecular weight standards (Gibco BRL, Gaithersburg, MQ) on the gels.

DNA SEQUENCING

Segments yielding positive results by PTT wete sequenced. PCR products were cloned intoca plasmid vector by either TA cloning or TOP( TA cloning (both Invitrogen, San Diego, CA DNA sequencing was performed by dye term nator cycle sequencing (Perkin-Elmer, Applied Biosystems Inc, Foster City, CA) and analyseg either at the Molecular Resource Center, Un versity of Tennessee, Memphis or at the Centक्ष̂r for Biotechnology, St Jude Children's Research Hospital. Sequencing primers were either the appropriate PTT reverse primer for a give् segment or a primer internal to the abnormal segment. The respective PTT primers (table $\Phi$ ) used for the following segments were: $95-1 \%$, PTT-1R; 96-77, PTT-2R; 96-53, PTT-3R; 96-45 and 96-65, PTT-4R; and 96-41, PTT9R. The following internal primers were used for sequencing, where primer sequences are designated by nucleotide positions and primer 
Table 1 continued

\begin{tabular}{|c|c|c|c|c|c|c|c|}
\hline $\begin{array}{l}\text { Cut } \\
\text { neurofib }\end{array}$ & $\begin{array}{l}\text { Optic } \\
\text { pathway } \\
\text { tumour }\end{array}$ & $\begin{array}{l}M R I \\
U B S\end{array}$ & $\begin{array}{l}\text { Cognitive } \\
\text { function }\end{array}$ & $\begin{array}{l}\text { Hyper- } \\
\text { telorism }\end{array}$ & $\begin{array}{l}\text { Macro- } \\
\text { cephaly }\end{array}$ & $\begin{array}{l}\text { Short } \\
\text { stature }\end{array}$ & Other \\
\hline+ & + & + & $\begin{array}{l}+\mathrm{LD} \\
+\mathrm{ADHD}\end{array}$ & - & - & + & E \\
\hline+ & - & - & $+\mathrm{LD}$ & - & - & + & $\mathrm{ACH}$ \\
\hline+ & + & + & $\begin{array}{l}+\mathrm{LD} \\
+\mathrm{ADHD}\end{array}$ & + & - & + & D F H I \\
\hline+ & ND & ND & ND & - & + & - & \\
\hline+ & - & - & ND & + & - & - & D \\
\hline+ & ND & ND & ND & + & - & - & $\mathrm{H}$ \\
\hline+ & - & ND & $+\mathrm{LD}$ & + & - & - & B \\
\hline+ & -- & + & $+\overline{L D}$ & + & - & - & \\
\hline- & - & + & $+\mathrm{LD}$ & + & - & - & \\
\hline+ & + & - & $+\mathrm{ADHD}$ & + & + & - & C \\
\hline+ & - & + & ND & + & - & + & $\mathbf{H}$ \\
\hline- & - & - & $+L D$ & + & - & - & \\
\hline+ & - & - & $\begin{array}{l}+\mathrm{LD} \\
+\mathrm{ADHD}\end{array}$ & + & + & -- & G \\
\hline+ & ND & ND & $+\mathrm{LD}$ & + & - & + & \\
\hline+ & - & - & $\begin{array}{l}+\mathrm{LD} \\
+\mathrm{ADHD}\end{array}$ & + & + & -- & I \\
\hline
\end{tabular}

orientation (F or $\mathrm{R}$ ) as in table 2: 95-15 and 96-62, CCAAGTCAAATAGCTTTTCTGC (736-757-R); 96-21, TGTGTATTGTCACTCGG (1293-1309-F); 96-45 and 96-65, CTTGCCTGGTCCAAATC (3199-3215-R); 96-43, AGGGAAACGCTGGCTAAC (41144131-R); 96-70, CCTTAAATGGCATAGTGTTTTGT (5376-5394-F) and CATTATGCTTGCAAAAACGAAC (5806-5827-R); and 96-42, CACTCTCTGTGTACTTG (6328-6344-F). Some abnormal segments were sequenced using more than one primer, and all abnormalities were identified in at least two independent clones. Mutations identified in CDNA were confirmed by direct sequencing of PCR products generated using genomic DNA and exon specific primers ${ }^{23}$ with one of the PCR primers used as a sequencing primer. Mutation names are according to recommendations of the Nomenclature Working Group, with the start site of translation denoted as nucleotide 1 for both cDNA and genomic DNA lesions. ${ }^{24}$

\section{Results}

LOCALISATION OF MUTATIONS BY PROTEIN TRUNCATION TEST

Mutation screening was performed by using RT-PCR and coupled in vitro transcription and translation to assess the coding potential of NF1 RNA. The normal mRNA includes $8.5 \mathrm{~kb}$ of coding sequence and encodes a protein product of 2818 amino acid residues. The approach used was similar to that of Heim et $a l,{ }^{11}$ but the sizes of individual segments were reduced. Additional primers were designed to divide the NF1 coding region into 10 segments of approximately $1.1 \mathrm{~kb}$ each (table 2 ) rather than the five $2 \mathrm{~kb}$ segments used in the previous study. The region of overlap between adjacent segments ranged in length from $205 \mathrm{bp}$ (segments 5 and 6) to 414 bp (segments 8 and 9). This corresponded to a minimum overlap of $8 \mathrm{kDa}$ between adjacent protein segments.

For each subject, RT-PCR was used to amplify all 10 overlapping segments. While most PCR reactions yielded a single band, several patient samples (95-15, 96-21, 96-62) showed abnormalities at the RT-PCR step (fig 1). Samples yielding RT-PCR products of reduced length subsequently were shown to skip exons (described below). In all subjects analysed, segment 5 yielded two closely spaced bands (data not shown), corresponding to alternative splicing of exon $23 \mathrm{a}^{25}$ In addition, for segment 7, all subjects yielded products of reduced size corresponding to alternative processing (skipping) of exons 29 and $30 .{ }^{26}$

RT-PCR products were subjected to coupled transcription and translation followed by protein gel electrophoresis. The normal protein banding pattern for each segment consisted of a predominant band corresponding to the expected full length product (range of approximately $38-43 \mathrm{kDa}$ for different segments) plus a predictable pattern of background bands (fig 2). As expected for subjects heterozygous for a dominant disorder, all specimens yielded full length product for each segment. In addition,

Table 2 Primer pairs for PTT

\begin{tabular}{|c|c|c|c|}
\hline Segment & Exons* & Nucleotidest & Sequence $\left(5^{\prime} \rightarrow 3^{\prime}\right) \neq \delta$ \\
\hline 1 & $1 \rightarrow 8$ & $(1-1094)$ & $\begin{array}{l}\text { F: (L)-ATGGCCGCGCACAGGCCGGTGGAAT } \\
\text { R: GAGAATGGCTTACTTGGATTAAA }\end{array}$ \\
\hline 2 & $6 / 7 \rightarrow 12 \mathrm{a} / 12 \mathrm{~b}$ & $(879-1868)$ & $\begin{array}{l}\text { F: (L)-ATGAATAAGAAGTTATTTCTGGACAG } \\
\text { R: TGACAGGAACTTCTATCTGCCTGCTTA }\end{array}$ \\
\hline 3 & $10 \mathrm{~b} \rightarrow 16$ & $(1484-2580)$ & $\begin{array}{l}\text { F: (L)-ATGGTGAAACTAATTCATGCAGAT } \\
\text { R: CAGGCCAGAATTGCTTCTCTG }\end{array}$ \\
\hline 4 & $14 \rightarrow 20$ & $(2278-3489)$ & $\begin{array}{l}\text { F: (L)-ATGGCACTGCTGAGGCGCATT } \\
\text { R: GTGCATGAGACCACTGTCTACG }\end{array}$ \\
\hline 5 & $19 b \rightarrow 25$ & $(3216-4364)$ & $\begin{array}{l}\text { F: (L)-ATGGAAGCAGTAGTTTCACTT } \\
\text { R: CGTGCTGCATCAAAGTTGC }\end{array}$ \\
\hline 6 & $24 \rightarrow 29$ & $(4160-5256)$ & $\begin{array}{l}\text { F: (L)-ATGTTCCTCAGATTTATCA } \\
\text { R: TAGGACTTTTGTTCGCTCTGCTGA }\end{array}$ \\
\hline 7 & $28 \rightarrow 32 / 33$ & $(4998-6100)$ & $\begin{array}{l}\text { F: (L)-ATGGAGTACACCAAGTATCATGAG } \\
\text { R: ACATCCTTCCAATAACCTTGC }\end{array}$ \\
\hline 8 & $31 \rightarrow 38$ & $(5878-6987)$ & $\begin{array}{l}\text { F: (L)-ATGACCATCAATGAAAAACAGATG } \\
\text { R: TATACGGAGACTATCTAAAGTATGCAG }\end{array}$ \\
\hline 9 & $34 / 35 \rightarrow 43$ & $(6573-7596)$ & $\begin{array}{l}\text { F: (L)-ATGGAGGCATGCATGAGAGATATTC } \\
\text { R: AGCCTTTGTGTCTGATATCAAG }\end{array}$ \\
\hline 10 & $41 \rightarrow 49$ & $(7354-8404)$ & $\begin{array}{l}\text { F: (L)-ATGGATACATATCCCATTCATCA } \\
\text { R: TCTGCACTTGGCTTGCGGAT }\end{array}$ \\
\hline
\end{tabular}

*Primers are either located within the exons given or span the junction of two adjacent exons (indicated by $/$ ). †Nucleotides are numbered from the start site of translation according to gb/M82814/HUMNF1AB.

‡Leader sequence $(L)$ for forward $(F)$ primers: GGATCCTAATACGACTCACTATAGGGCCGCCACC-

\$The following primer sequences are from Heim et $a l^{\prime \prime}: 1 \mathrm{~F}, 2 \mathrm{R}, 3 \mathrm{~F}, 5 \mathrm{~F}, 6 \mathrm{R}, 7 \mathrm{~F}, 8 \mathrm{R}, 9 \mathrm{~F}, 10 \mathrm{R}$. In that paper, the primers are named $1 F, 1 R, 2 F, 3 F, 3 R, 4 F, 4 R, 5 F$, and $5 R$, respectively. 
A
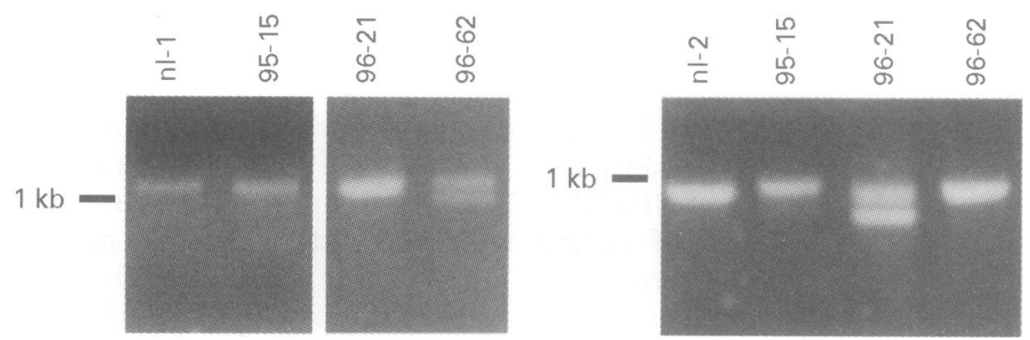

Figure 1 Representative RT-PCR products for segments 1 and 2. (A) Segment 1, normal control and subjects 95-15, 96-21, and 96-62. (B) Segment 2, normal control and subjects 95-15, 96-21, and 96-62. Each normal control illustrates the expected full length RT-PCR product for that segment. Cases of aberrant splicing yielded both full length product and deleted product, as seen for segment 1 in $(A)$ 95-15 and 96-62 and for segment 2 in (B) 96-21. RT-PCR products were resolved on $1 \%$ agarose gels.
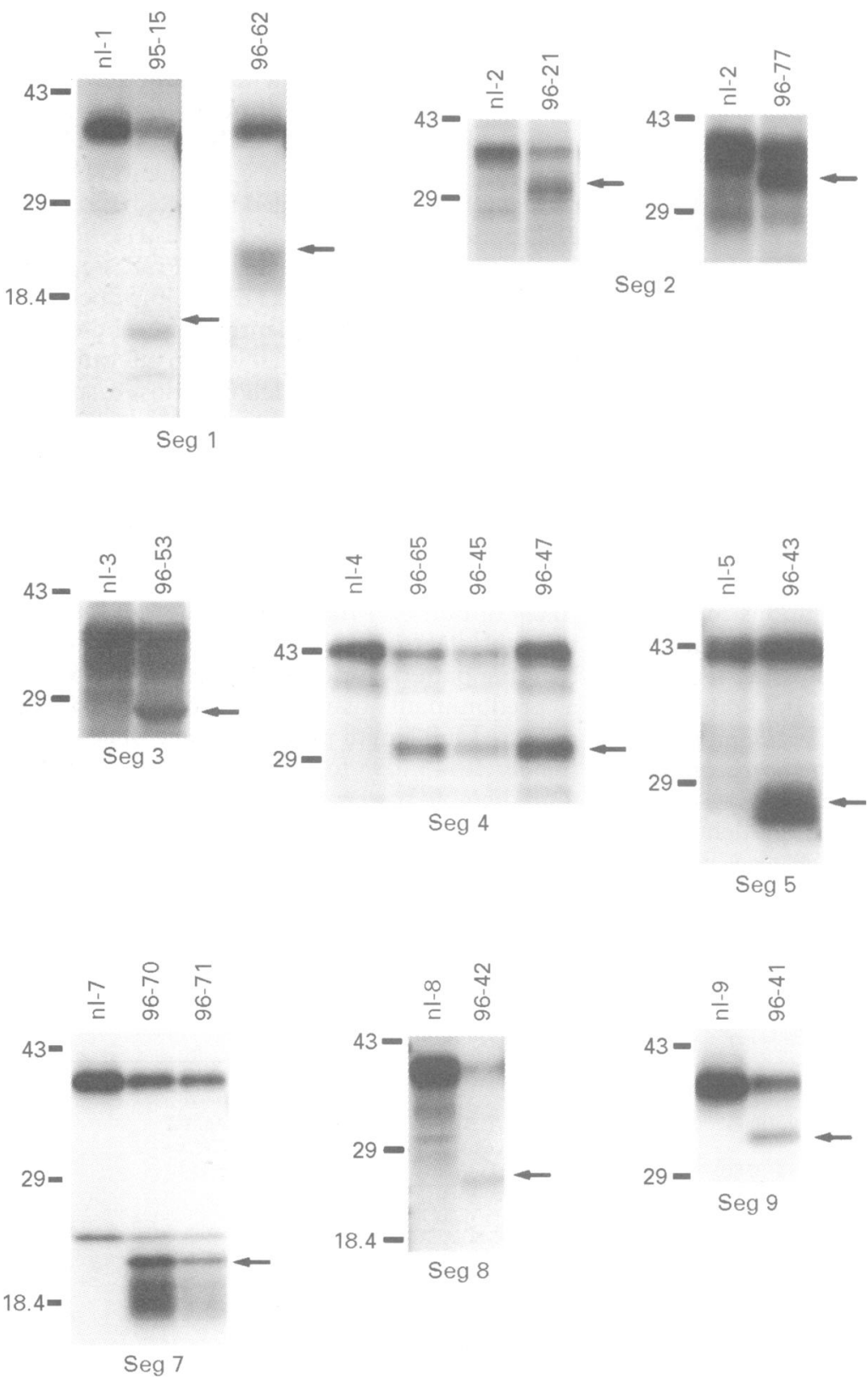

Figure 2 Composite of protein gels showing positive PTT results. The position of each abnormal, truncated protein is indicated by an arrow. A normal control (nl) is shown to the left of each patient sample, and the segment (Seg) is identified below each panel. Migration of protein molecular weight standards is indicated (in $k D a$ ) to the left of each panel.

truncated products were observed in a single segment from 11 of the 15 subjects analysed. Truncated products ranged in size from approximately 18 to $34 \mathrm{kDa}$. The 11 positives were distributed throughout the gene, with one or two truncating mutations identified in each segment, except for segments 6 and 10 where no positives were identified in this series.

Within the families reported here, mutatio screening by PTT was reliable and reproduc ible. In two families, multiple affected subjects were tested and consistent results were ob tained (fig 2, seg 4 (96-65, 96-45, 96-47) an seg 7 (96-70, 96-71)). In all cases, mutation subsequently identified by sequencing were consistent with the observed sizes of truncateg protein products.

\section{IDENTIFICATION OF MUTATIONS BY DNA}

SEQUENCING

The 11 segments yielding positive results $\vec{P}$ PTT were sequenced (table 1 , fig 3 ). Teñ different mutations were identified, including four splice errors, three small deletions, tw nonsense mutations, and one $1 \mathrm{bp}$ insertion.

The four splice aberrations (96-21, 96-62\% 96-42, and 95-15) all involved exon skipping and all but 96-21 introduced a change in read웅 ing frame consistent with premature termina tion of translation. In 96-21, the skipped exom (10b) caused an in frame deletion of $135 \mathrm{~b} \overrightarrow{\mathrm{B}}$ (1393-1527del) corresponding to eliminatio of 45 amino acids; this was consistent with the size shift of approximately $5 \mathrm{kDa}$ observed b PTT. Cases 96-62 and 96-42 skipped exon 4 $\overrightarrow{0}$ (587-654del) and exon 35 (6580-6641delog respectively. A complex pattern of aberrant splicing was observed in 95-15 (describee below).

To investigate the genomic basis of exo skipping, specific exons were amplified fron genomic DNA and used for direct sequencin (exons $4 b$ and $4 c$ of $95-15$, exon $4 c$ of $96-623$ exon $10 \mathrm{~b}$ of $96-21$, and exon 35 of 96-42) Observations of possible heterozygosities were followed by cloning the appropriate PCR products and sequencing multiple individuas clones. Two patients (96-42 and 96-62) werg heterozygous for splice site mutations. Subject 96-42 carried a $G$ to $T$ substitution of the firs base of intron $35(6641+1 \mathrm{G}>\mathrm{T})$. In 96-62, a to A substitution was observed in the splice acceptor site of intron $4 \mathrm{~b}(587-3 \mathrm{C}>\mathrm{A})$. In sub? ject 96-21, no splice site abnormalities were found to explain the in frame deletion of exor 10b. However, a missense mutation was identin fied near the 3 ' end of exon $10 \mathrm{~b}$. Substitution of $\mathrm{G}$ for $\mathrm{A}$ at nucleotide 1513 corresponded to $\mathrm{z}$ non-conservative amino acid substitution of glutamic acid for lysine (K505E). Both unaf fected parents of subject 96-21 were studie and neither exhibited either the 1513A>Go substitution in genomic DNA or skipping oథ exon $10 \mathrm{~b}$ in cDNA (data not shown). The parental studies are consistent with $1513 \mathrm{~A}>\&$ being a de novo disease causing mutation iq subject 96-21. Additional studies are im progress to evaluate the relationship betweero the observed missense mutation and the aber rant splicing of exon $10 \mathrm{~b}$. In the fourth patient (95-15), no genomic defect was detected in either exon $4 b$ or $4 c$.

The other mutations identified were sequence changes involving one to four base pairs. An identical deletion of 2 bp (3151- 


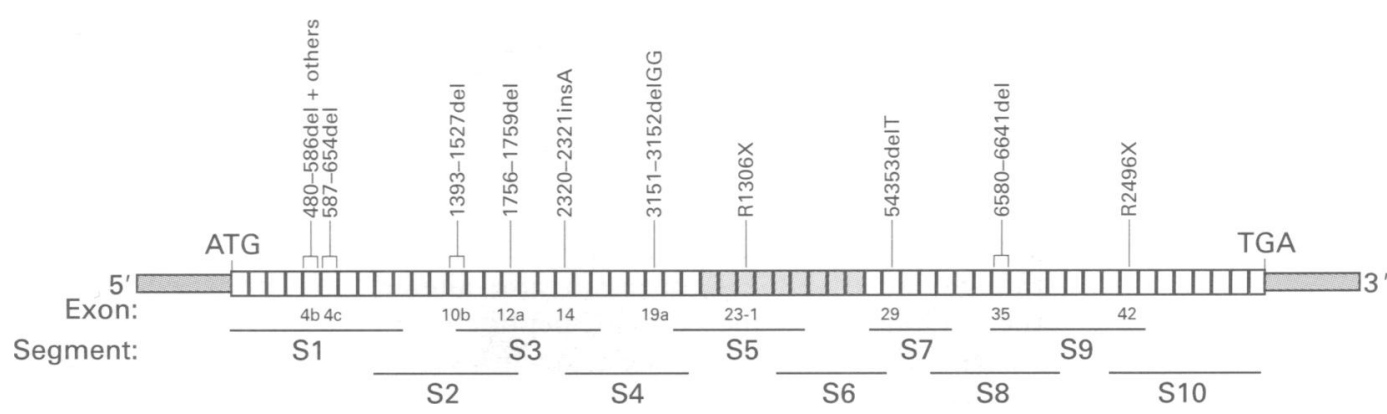

Figure 3 Mutations identified by PTT. Mutations are aligned above a map of the NF1 cDNA, with each exon represented by a small box (not drawn to scale). Brackets represent mutations that skip exons, as indicated. Relative positions of the 10 segments used for PTT are indicated below the map. Abbreviations: del (deletion), $R$ (arginine), $X$ (stop codon). Nucleotides are numbered from the start site of translation.

3152delGG) was identified in two patients (96-45 and 96-65). More extensive family histories showed that the people tested were members of a common lineage (probands were second cousins). Other small deletions of $1 \mathrm{bp}$ (5453delT) and $4 \mathrm{bp}(1756-1759 \mathrm{del})$ were observed in patients 96-70 and 96-77, respectively. An insertion of 1 bp (2320-2321insA) was detected in 96-53. All four mutations altered the reading frame, and in each case the new reading frame contained a stop codon shortly downstream of the mutation site (table 1). Two nonsense mutations, R1306X and R2496X, were identified in patients $96-43$ and 96-41, respectively. Both mutations were $C$ to $\mathrm{T}$ transitions, converting arginine codons to stop codons. R1306X, observed as a constitutional mutation in 96-43, is identical to a previously reported mRNA edit in $\mathrm{NF}^{27} 28$ (see Discussion). The mutation R2496X, found in an affected subject with no family history of NF1, was previously reported in a Scottish patient. ${ }^{3}$ Other than R2496X, the mutations reported here have not been previously described. ${ }^{29}$ Following identification in cDNA clones, all six mutations were confirmed in genomic DNA by direct sequencing of the appropriate PCR amplified exon (data not shown).
COMPLEX ABERRANT SPLICING WITH MULTIPLE SKIPPED EXONS AND AN INSERTION

Patient 95-15 exhibited protein truncation within segment 1 . RT-PCR analyses showed the presence of at least two products, the full length segment 1 product $(1.1 \mathrm{~kb})$ and a shorter product of approximately $0.5 \mathrm{~kb}$ (fig 1A). PTT showed a truncated protein of approximately $18 \mathrm{kDa}$ (fig 2 , segment 1 ). Subsequent studies of cloned RT-PCR products showed five different splicing errors (fig 4A), each observed in two independent clones. Four of the five errors included skipping of exon $4 \mathrm{~b}$. The first error was skipping of exon $4 \mathrm{~b}$ only (480-586del). The second class of aberrant transcripts skipped four contiguous exons, 2 to $4 \mathrm{~b}$ (61-586del), whereas the third skipped exons $4 \mathrm{~b}$ and 7 while retaining the intervening exons 4c, 5, and 6 (480-586del; 889-1062del). The last two classes of splice errors involved both a novel insertion and exon skipping. One class skipped exon $4 \mathrm{~b}$ and contained a novel 31 bp sequence in its place (9479-480ins $31 \mathrm{bp}$; 480-586del) (fig 4B). Another class contained the same $31 \mathrm{bp}$ sequence between exons $4 \mathrm{a}$ and $4 \mathrm{~b}$ and then skipped exons $4 \mathrm{c}, 5$, and 6 (479-480ins31bp; 587-888del). A search of sequence databases failed to show homologies to the novel $31 \mathrm{bp}$ sequence.

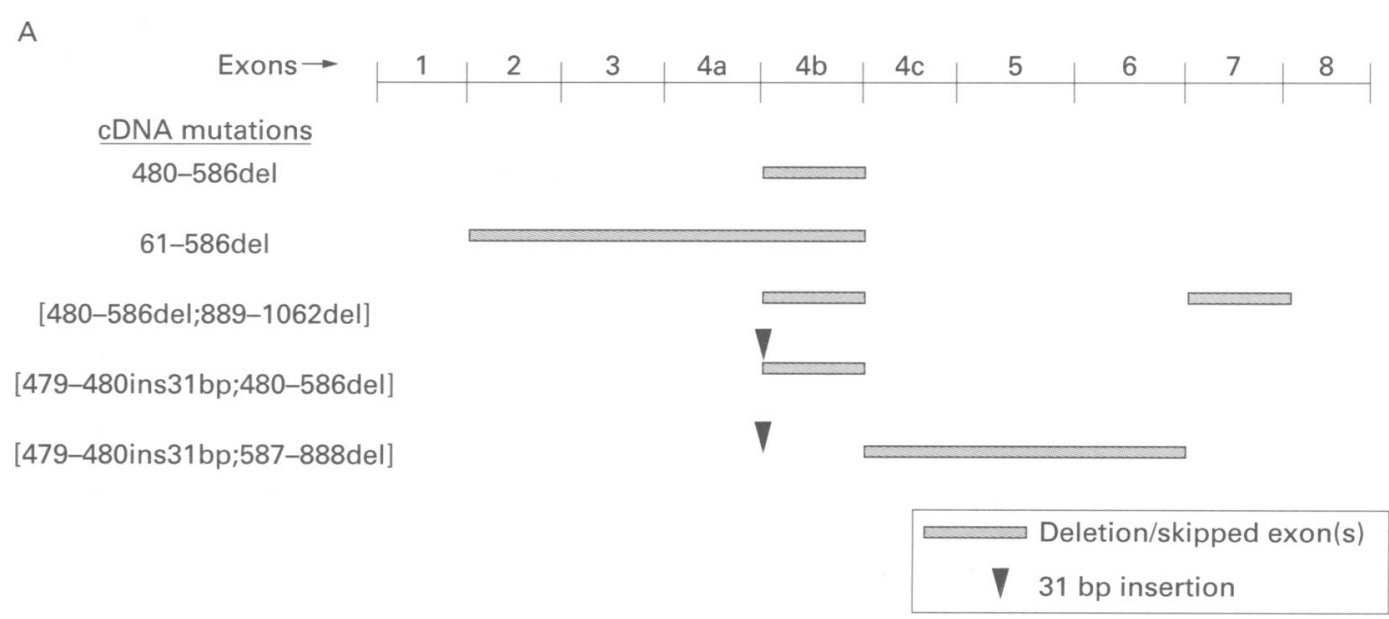

Figure 4 Multiple splice errors in patient 95-15. (A) Exons normally present in segment 1 are shown at the top with the observed aberrant splice products indicated below. Hatched bars represent the exons skipped in each abnormal transcript. An inverted triangle indicates the presence of a novel $31 \mathrm{bp}$ sequence. (B) Sequence of the $31 \mathrm{bp}$ insertion, represented as an inverted triangle above. 
Four of the five aberrant transcripts (all except 61-586del) introduced stop codons just downstream of exon $4 \mathrm{a}$. These four were predicted to encode protein products of similar size (approximately $19 \mathrm{kDa}$ ), which was in good agreement with the observed truncated protein band of approximately $18 \mathrm{kDa}$. Although the 61-586del transcript also altered the reading frame, the encoded peptide of 28 amino acids ( $3.4 \mathrm{kDa}$ ) would be below the resolving power of the gel system and was not observed. Interestingly, the shortened band of $0.5 \mathrm{~kb}$ seen by RT-PCR (fig $1 \mathrm{~A}$ ) corresponded in size with 61-586del, whereas the other aberrantly spliced RT-PCR products were only marginally visible by agarose gel electrophoresis. All abnormalities observed in this patient predicted severe protein truncation and probably complete loss of function in vivo.

\section{Discussion}

Mutation screening in NF1 has been hindered by the large size of the gene and by the random distribution of disease causing mutations. We used a protein truncation test to screen the entire coding region in $15 \mathrm{NF} 1$ patients and detected 10 different mutations in 11 patients. By reducing the sizes of the segments screened from approximately $2 \mathrm{~kb}^{11}$ to approximately 1.1 $\mathrm{kb}$, we achieved consistently high yields of RT-PCR product, which were associated with good resolution and low background on protein gels. The newly reported mutations were distributed throughout the gene and included nine truncating mutations (seven frameshift and two nonsense) and one in frame deletion. Four splice errors were detected and all involved exon skipping. The current study adds to the growing body of reports showing the usefulness of PTT for mutation screening in disorders where disease causing mutations are heterogeneous and loss of function mutations are common.

\section{PROTEIN TRUNCATION ASSAY}

In spite of its apparent strengths, protein truncation screening has limitations. Missense mutations are not detected, as these do not affect the size of the encoded protein. When used as an RNA based assay, PTT cannot detect mutant alleles associated with very rare or absent mRNA. Although no systematic evaluations have been reported, $10-20 \%$ of normal mRNA levels has been suggested as a lower detection limit. ${ }^{14}$ Thus, large gene deletions and mutations associated with low mRNA abundance will be missed. In NF1, large deletions and missense mutations are associated with disease ${ }^{29}$ and allelic instability of NF1 mRNA has been reported. ${ }^{30}$ These factors, which are beyond the capabilities of PTT, limit the sensitivity of the method in screening affected subjects.

Technical limitations of the assay itself may also account for false negative results. A truncating mutation may be missed if it causes segment specific amplification failure. When one or more segments from an abnormal allele fail to amplify, the observed product represents only the normal allele rather than both gene copies. Since PTT is not quantitative, an apparently normal result is obtained. Segment specific amplification failure may occur be cause a mutation destroys one or more primes annealing sites or because of the presence of large insertion that increases the size of $\Phi$ particular segment beyond the length that caif be amplified. The overlap between adjacent segments provides partial protection agains false negatives caused by amplification failure? since a mutation that destroys one priming site should be picked up as a truncating eventa within the overlapping segment. Two muta tions reported here illustrate successful use of this safeguard. The mutation 1393-1527dép skips exon $10 \mathrm{~b}$, which contains the forwar $\Phi$ priming site for segment 3, and 6580-6641 de广 skips exon 35, which contains the forward priming site for segment 9 . Each mutation wa detected as a result of truncation within the्ट respective upstream segment (2 or 8 ). How ever, a somewhat larger deletion, encompasse $\vec{e}$ ing the region of overlap between two adjacenie segments, would be missed since one prime annealing site from each segment would be destroyed. ${ }^{10}$ Truncating mutations may also $b \vec{\varepsilon}$ missed if the size of the truncated product fallo outside the resolving ability of the protein ges system (for example, 61-586del in 95-15).

No accurate estimate is available of the relaco tive contributions of various factors in limitingo the sensitivity of PTT. Of particular interest is the percentage of truncating mutations that are missed. In one review, ${ }^{2} 80 \%$ of fully character ised mutations detected by methods other that PTT were associated with a significant chang: in protein size. In other studies using PTT fo mutation screening in NF1, detection rate were $67 \%$ ( 14 mutations in 21 subjects), ${ }^{11} 54 \%$ (seven mutations in 13 subjects), ${ }^{20}$ and $44 \%$ (eight mutations in 18 subjects). ${ }^{19}$ In combinas. tion with the present study, PTT has identifies $40 \mathrm{NF} 1$ mutations in 67 affected subjects $(60 \%)$. Thus, an approximation of the sensitiv. ity of PTT in detecting truncating mutations is $75 \%(60 / 80)$. Interestingly, the study with the lowest detection rate ${ }^{19}$ evaluated children with myeloid malignancies and used affected tissu (bone marrow) for mutation screening in the majority of cases. As suggested by thos N authors, destabilisation of RNA may be d significant factor limiting the efficiency of PT त्लि

MUTATIONS

The mutations described here are consisten with previous reports in failing to identif mutational hotspots within the NF1 gene.? While there is no apparent predominant mech anism for NF1 mutations, as a group the mutations are representative of naturally occure ring mutations in the human genome. ${ }^{31}{ }^{32}$ The three short deletions and single insertion alf occurred within some type of short sequenco repeat and presumably arose through the com mon mutational mechanism of slipped stran mispairing. ${ }^{31}{ }^{33}$ The single base pair insertion, 2320-2321 insA, occurred within the sequence "AACAC", changing it to a direct repeat, "AACAAC". The 2 bp deletion, 31513152 delGG, removed two of three consecutive 
$\mathrm{G}$ residues. 5453del $\mathrm{T}$ involved the deletion of a thymine adjacent to five $\mathrm{C}$ residues. The mutation 1756-1759del (deletion of the $4 \mathrm{bp}$ sequence "ACTA") removed one flanking $2 \mathrm{bp}$ repeat ("TA") plus the sequence between repeats (" $A C$ ") from the normal sequence "TAACTA". The other sequence changes observed in genomic DNA were either transitions $(1513 \mathrm{~A}>\mathrm{G}, 3916 \mathrm{C}>\mathrm{T}, 7486 \mathrm{C}>\mathrm{T})$ or transversions $(587-3 \mathrm{C}>\mathrm{A}$ and $6641+1 \mathrm{G}>\mathrm{T})$.

The most common abnormalities detected in cDNA were splice errors. Two examples of exon skipping associated with splice site abnormalities were found (splice donor site mutation in 96-42 and splice acceptor site mutation in 96-62). In a third case (96-21), the only mutation found in the skipped exon (10b) was a missense mutation located $15 \mathrm{bp}$ from the $3^{\prime}$ end of exon $10 \mathrm{~b}$ and encoding a non-conservative amino acid substitution (Lys to Glu). Although we have not proved such a relationship in this case, other examples of exon based mutations affecting exon recognition have been reported. These have included cases where exon skipping was induced by silent mutations, ${ }^{34}$ missense mutations, ${ }^{35}{ }^{36}$ and nonsense mutations. ${ }^{37-39}$ Aberrantly spliced NF1 transcripts, including skipped exons, were also observed in other reports of RNA based mutation screening. ${ }^{11} 19$ Aberrant splicing appears to be a frequent cause of protein truncation.

The fourth case of aberrant splicing (95-15) exhibited multiple abnormal transcripts involving both exon skipping and a small insertion of unknown origin (fig 4). Based on the position of the insertion, it most probably consisted of sequences from intron $4 \mathrm{a}$, which has not yet been completely sequenced. Although the most straightforward explanation for the insertion is inclusion of $31 \mathrm{bp}$ of intron $4 \mathrm{a}$ through the use of cryptic splice sites, more complex possibilities, such as a germline insertion, cannot be ruled out. Additional studies to identify the genomic basis of the aberrant splicing in this patient are in progress.

In subject 96-43 a nonsense mutation was identified which is identical to a reported edit site in exon 23-1 of NF1 mRNA. ${ }^{27} 28$ In the mRNA edit, post-transcriptional base modifcation converts the normal cytosine at position 3916 to a uracil, thus changing an arginine to a stop codon. The edited transcript accounts for approximately $2 \%$ of NF1 mRNA in normal subjects. ${ }^{27}$ In subject $96-43$, sequencing showed the presence of a $\mathrm{C}$ to $\mathrm{T}$ transition $(3916 \mathrm{C}>\mathrm{T})$ in genomic DNA, thus confirming the presence of a bona fide nonsense mutation, rather than increased mRNA editing (data not shown). Subject 96-43 had typical NF1 and is an apparent new mutation (table 1). Absence of the $3916 \mathrm{C}>\mathrm{T}$ mutation was shown in blood from the subject's unaffected mother, but the reportedly unaffected father was not available for testing. Assuming that this is indeed the patient's disease causing mutation, it suggests a pathogenic potential of the sequence change, and this is consistent with the increased level of edited mRNA seen in some tumours. ${ }^{27}{ }^{40}$ The role of the mRNA edit in normal subjects is unknown.

\section{PHENOTYPIC FEATURES}

Clinical features of the study population were typical with respect to NF1 phenotype (table 1), although an unexpected incidence of orbital and ocular manifestations of NF1 was observed, including hypertelorism, ptosis, strabismus, and partial iris heterochromia. Twelve of 15 study participants (80\%) exhibited hypertelorism. Hypertelorism has been noted as a component of the facial dysmorphism seen in some severely affected patients with large gene deletions. ${ }^{41}{ }^{42}$ However, none of our study participants displayed the Noonan-NF phenotype. ${ }^{4344}$ In typical NF1 patients, the incidence of hypertelorism has been reported as approximately $25 \%$ (eight of 34 patients). ${ }^{45}$ We have determined interpupillary distances in 44 patients (including the 15 described in this report) and found hypertelorism in $61 \%$ (27 of 44). ${ }^{46}$ Hypertelorism may be relatively common in NF1 patients, representing one aspect of mildly abnormal orbital development. ${ }^{47}$

Interestingly, partial iris heterochromia was observed in two unrelated subjects (96-62, 96-42). Both carried truncating mutations caused by exon skipping, but the mutations were at opposite ends of the gene (exons $4 \mathrm{c}$ and 35 , respectively), and no common mechanism was apparent. Although heterochromia of the iris has been reported in association with $\mathrm{NF} 1^{48}$ and may be another manifestation of NF1 associated neurocristopathy, its significance is unknown.

A primary goal of mutation screening, correlations between genotype and disease phenotype, continues to be difficult in NF1. In addition to efficient methods of mutation identification, more studies of gene function, protein function, and the genetic basis of disease progression are needed to understand the pathogenesis of this complex disease.

\section{Note added in proof}

The $31 \mathrm{bp}$ cDNA insertion observed in patient 95-15 (fig 4B) is from intron $4 \mathrm{a}$ (gb/ AC004222/AC004222). Cryptic splicing of this sequence has been observed by others in some NF1 tumours ( $M$ R Wallace, unpublished results).

Expert technical assistance was provided by Ms Kathleen Kenwright and Ms Dawn Sturtevant. We thank the patients and their families for their participation and also Ms Marcella Lawrence for her assistance in study enrolment. We thank Dr Ruth Heim for her assistance and helpful comments. This work was supported by the Crippled Children's Foundation Research Center of LeBonheur Children's Medical Center and the Herbert and Mary Shainberg Neuroscience Research Program.

1 Gutmann DH, Aylsworth A, Carey JC, et al. The diagnostic evaluation and multidisciplinary management of neurofibromatosis 1 and neurofibromatosis 2. $\mathscr{f} A M A$ 1997;278:51-7.

2 Shen MH, Harper PS, Upadhyaya M. Molecular genetics of neurofibromatosis type 1 (NF1). $\mathcal{F}$ Med Genet 1996;33:217.

3 Purandare SM, Lanyon WG, Connor JM. Characterisation of inherited and sporadic mutations in neurofibromatosis type-1. Hum Mol Genet 1994;3:1109-15.

4 Upadhyaya M, Osborn MJ, Maynard J, Kim MR, Tamanoi F, Cooper DN. Mutational and functional analysis of the neurofibromatosis type 1 (NF1) gene. Hum Genet 1997;99: 88-92. 
5 Upadhyaya $M$, Osborn M, Maynard J, Harper P. Characterization of six mutations in exon 37 of neurofibromatosis type 1 gene. Am f Med Genet 1996;67:421-3.

6 Shen MH, Harper PS, Upadhyaya M. Neurofibromatosis type 1 (NF1): the search for mutations by PCRheteroduplex analysis on Hydrolink gels. Hum Mol Genet 1993;2:1861-4

7 Robinson PN, Buske A, Neumann R, Tinschert S, Nürnberg P. Recurrent 2-bp deletion in exon 10c of the NF1 gene in two cases of von Recklinghausen neurofibromatosis. Hum Mutat 1996;7:85-8

8 Gasparini P, D’Agruma L, de Cillis P, Balestrazzi P, Mingarelli R, Zelante L. Scanning the first part of the neurofibromatosis type 1 gene by RNA-SSCP: identification of three novel mutations and of two new polymorphisms. Hum Genet 1996;97:492-5.

9 Abernathy CR, Rasmussen SA, Stalker HJ, et al. NF1 mutation analysis using a combined heteroduplex/SSCP approach. Hum Mutat 1997;9:548-54.

10 Martinez JM, Breidenbach HH, Cawthon R. Long RT-PCR of the entire $8.5-\mathrm{kb} \mathrm{NF} 1$ open reading frame and mutation detection on agarose gels. Genome Res 1996;6:58-66.

11 Heim RA, Kam-Morgan LNW, Binnie CG, et al. Distribution of 13 truncating mutations in the neurofibromatosis tion of 13 truncating mutations in the

12 Powell SM, Petersen GM, Krush AJ, et al. Molecular diagnosis of familial adenomatous polyposis. $N$ Engl f Med 1993;329:1982-7.

13 Roest PAM, Roberts RG, Sugino S, van Ommen G-JB, den Dunnen JT. Protein truncation test (PTT) for rapid detection of translation-terminating mutations. Hum Mol Genet 1993;2:1719-21.

14 Hogervorst FBL, Cornelis RS, Bout M, et al. Rapid detection of BRCA1 mutations by the protein truncation test. Nat Genet 1995;10:208-12.

15 Lancaster JM, Wooster R, Mangion J, et al. BRCA2 mutations in primary breast and ovarian cancers. Nat Gene 1996;13:238-40

16 Telatar M, Wang Z, Udar N, et al. Ataxia-telangiectasia: mutations in ATM cDNA detected by protein truncation screening. Am f Hum Genet 1996;59:40-4.

17 van Bakel I, Sepp T, Ward S, Yates HRW, Green AJ. Mutations in the TSC2 gene: analysis of the complete coding sequence using the protein truncation test (PTT). Hum sequence using the protein

18 Liu B, Parsons R, Papadopoulos N, et al. Analysis of mismatch repair genes in hereditary non-polyposis colorectal cancer patients. Nat Med 1996;2:169-74.

19 Side L, Taylor B, Cayouette M, et al. Homozygous inactivation of the NF1 gene in bone marrow cells from children with neurofibromatosis type 1 and malignant myeloid with neurofibromatosis type 1 and mali

20 Messiaen LM, Callens T, De Paepe A, Mortier G. Identification of 9 different NF1 mutations in 13 unrelated Belgian patients using the combined approach of the protein truncation assay and heteroduplex analysis. $\mathrm{Am} f$ Hum Genet 1997;61:A74.

21 Stumpf DA, Allesne JF, Annegars JF, et al. NIH Consensus Development Conference: neurofibromatosis conference statement. Arch Neurol 1988;45:575-8.

22 Chomzcynski P, Sacchi N. Single-step method of RNA isolation by acid guanidinium thiocyanate-phenol-chloroform lation by acid guanidinium thiocyanate-ph

$23 \mathrm{Li} \mathrm{Y}, \mathrm{O}$ 'Connell P, Breidenbach $\mathrm{HH}$, et al. Genomic organization of the neurofibromatosis 1 gene (NF1). Genomics 1995;25:9-18.

24 Antonarakis SE, Ashburner M, Auerbach AD, Beaudet AL Beckmann JS. Recommendations for a nomenclature system for human gene mutations. Hum Mutat 1998;11:13 .

25 Andersen LB, Ballester R, Marchuk DA, et al. A conserved alternative splice in the von Recklinghausen neurofibromatosis (NF1) gene produces two neurofibromin isoforms, both of which have GTPase-activating protein activity. Mo Cell Biol 1993;13:487-95.

26 Park VM, Pivnick EK. Neurofibromatosis type 1 (NF1) gene: alternative splicing of exons 29 and 30 and a novel brain-specific transcript. Am $\mathcal{f}$ Hum Genet 1997;61:A180.
27 Cappione AJ, French BL, Skuse GR. A potential role for NF1 mRNA editing in the pathogenesis of NF1 tumors. Am f Hum Genet 1997;60:305-12.

28 Skuse GR, Cappione AJ, Sowden M, Metheny LJ, SmitkHC. The neurofibromatosis type 1 messenger RNA under 3 goes base-modification RNA editing. Nucleic Acids ReA 1996;24:478-85.

29 Korf B. NNFF International NF1 Genetic Analysi Consortium Database. World Wide Web URL: http:洛 www.clam.com/nf/nf1gene/ 1997.

30 Hoffmeyer S, Assum G, Griesser J, Kaufmann D, Nürnberg $P$, Krone W. On unequal allelic expression of th neurofibromin gene in neurofibromatosis type 1. Hum Mot Genet 1995;4:1267-72.

31 Cooper DN, Krawczak M, Antonarakis SE.The nature an mechanism of human gene mutation. In: Scriver $\mathrm{CR}_{\bar{G}}$ Beaudet AL, Sly WS, Valle D, eds. The metabolic and molecular bases of inherited disease. New York: McGraw-Hill 1995:259-91.

32 Antonarakis SE. Mutations in human disease: nature an $\AA^{\$}$ consequences. In: Rimoin DL, Connor JM, Pyeritz RE eds. Emery and Rimoin's principles and practice of medical genetics. New York: Churchill Livingstone: 1996:53-66.

33 Streisinger G, Okada Y, Emrich J, et al. Frameshiff mutations and the genetic code. Cold Spring Harbor Sym Quant Biol 1966;31:77.

34 Liu W, Qian C, Francke U. Silent mutation induces exon skipping of fibrillin-1 gene in Marfan syndrome. Nat Gene 1997; 16:328-9.

35 Ronce N, Moizard MP, Robb L, Toutain A, Villard L $\overrightarrow{0}$ Moraine C. A C2055T transition in exon 8 of the ATP7AD gene is associated with exon skipping in an occipital horr $\vec{\omega}$ syndrome family. Am f Hum Genet 1997;61:233-8.

36 Das S, Levinson B, Whitney S, Vulpe C, Packman S? Gitschier J. Diverse mutations in patients with Menkes dis $\rightarrow$ ease often lead to exon skipping. Am $\mathcal{F}$ Hum Genet 1994;55O 883-9.

37 Dietz HC, Kendzior RJ. Maintenance of an open readin frame as an additional level of scrutiny during splice site selection. Nat Genet 1994;8:183-8.

38 Maquat LE. Defects in RNA splicing and the consequencer of shortened translational reading frames. Am $\mathcal{F ~ H u m ~ G e n e \& O}$ 1996;59:279-86.

39 Messiaen L, Callens T, DePaepe A, Craen M, Mortier GD Characterization of two different nonsense mutations? C6792A and C6792G, causing skipping of exon 37 in the NF1 gene. Hum Genet 1997;101:75-80.

40 Skuse GR,Cappione AJ. RNA processing and clinicab variability in neurofibromatosis type 1 (NF1). Hum Mo $\frac{\mathbb{Q}}{\mathbb{Q}}$ Genet 1997;6:1707-12.

41 Kayes LM, Burke W, Riccardi VM, et al. Deletions spanning the neurofibromatosis 1 gene: identification and phenotype of five patients. Am ₹ Hum Genet 1994;54:424-36.

42 Wu BL, Austin MA, Schneider GH, Boles RG, Korf BR Deletions of the entire NF1 gene detected by FISH: fouro deletion patients associated with severe manifestations. $A n \dot{ }$ 7 Med Genet 1995;59:528-35.

43 Colley A, Donnai D, Evans DGR. Neurofibromatosis Noonan phenotype: a variable feature of type 1 neurofi bromatosis. Clin Genet 1996;49:59-64

44 Stern HJ, Saal HM, Lee JS, et al. Clinical variability of type I neurofibromatosis: is there a neurofibromatosis-Noonano syndrome? $\mathcal{F}$ Med Genet 1992;29:184-7.

45 Westerhof W, Delleman JW, Wolters E, Dijkstra P. Neurofibromatosis and hypertelorism. Arch Dermatol 1984;120음 1579-81.

46 Pivnick EK, Schaefer GB, Lin AE, et al. Delineation of common facial appearance in neurofibromatosis type $1=$ (NF1). Am 7 Hum Genet 1997;61:A1 10.

47 Kaste SC, Pivnick EK. Bony orbital morphology in neurofis bromatosis type 1 (NF1). $\mathcal{F}$ Med Genet 1998;35:628-31. N

48 Ragge NK. Clinical and genetic patterns of neurofibromato+N sis 1 and 2. Br f Ophthalmol 1993;77:662-72. 